University of Michigan Law School

University of Michigan Law School Scholarship Repository

Articles

Faculty Scholarship

1985

\title{
The Supreme Court's Misconstruction of a Procedural Statute-A Critique of the Court's Decision in Badaracco
}

Douglas A. Kahn

University of Michigan Law School, dougkahn@umich.edu

Available at: https://repository.law.umich.edu/articles/310

Follow this and additional works at: https://repository.law.umich.edu/articles

Part of the Legislation Commons, Supreme Court of the United States Commons, TaxationFederal Commons, and the Tax Law Commons

\section{Recommended Citation}

Kahn, Douglas A. "The Supreme Court's Misconstruction of a Procedural Statute-A Critique of the Court's Decision in Badaracco." Mich. L. Rev. 82 (1983): 461-85.

This Article is brought to you for free and open access by the Faculty Scholarship at University of Michigan Law School Scholarship Repository. It has been accepted for inclusion in Articles by an authorized administrator of University of Michigan Law School Scholarship Repository. For more information, please contact mlaw.repository@umich.edu. 


\section{THE SUPREME COURT'S \\ MISCONSTRUCTION OF A PROCEDURAL \\ STATUTE - A CRITIQUE OF THE \\ COURT'S DECISION IN \\ $B A D A R A C C O$}

Douglas A. Kahn*

When a taxpayer files an honest ${ }^{1}$ federal income tax return for a taxable year, section 6501(a) of the Internal Revenue Code ${ }^{2}$ limits the period of time during which the Government can assess a tax for that year to a three-year period commencing with the date that the return was filed. The three-year limitations period is extended for an additional three years by section $6501(\mathrm{e})(1)(\mathrm{A})$ if the taxpayer's return omits properly includible gross income in an amount in excess of twenty-five percent of the gross income that was reported. If a taxpayer fails to file a return for a taxable year or files a fraudulent return, sections 6501(c)(1) and (c)(3) permit the tax for that year to be assessed at any time; in other words, there is no limitation on the time available to the Government to assess or collect the tax.

If a taxpayer who failed to file a timely return for a taxable year subsequently files an honest delinquent return, the three-year limitations period commences to run from the date that the delinquent return is filed no matter how tardy it is and irrespective of whether the taxpayer had a fraudulent purpose for failing to file on time. ${ }^{3}$ On the other hand, the Supreme Court recently held that a taxpayer who initially files a fraudulent income tax return cannot invoke a period of limitations by filing an honest amended return correcting

* Professor of Law, University of Michigan. - Ed.

The author consulted with an attorney for one of the petitioners in the Badaracco case on the preparation of a brief in the Supreme Court. While the author sincerely believes that his views on the proper construction of the statute in question and his condemnation in this Article of the Court's reasoning were arrived at independently of his association with that case, the reader is the best judge of the merits of the author's views and whether condemnation of the Court is warranted.

1. An honest return is one in which deficiencies, if any, are attributable to bona fide differences of judgment or to innocent errors caused by oversight or negligence.

2. Unless otherwise indicated, any reference herein to a section number will refer to a section of the Internal Revenue Code of 1954.

3. I.R.C. $\$ 6501$ (a) (1982); Bennett v. Commissioner, 30 T.C. 114, 123 (1958), acq., 1958-2 C.B. 3. See Badaracco v. Commissioner, 52 U.S.L.W. 4081, 4082 (U.S. Jan. 17, 1984); Rev. Rul. 79-178, 1979-I C.B. 435. 
the fraudulent aspects of the original return. The Supreme Court held in Badaracco v. Commissioner ${ }^{4}$ that once a fraudulent return has been filed, there is no limitation on the time available to the Government to assess a tax deficiency and penalties for that year regardless of corrective action taken by the taxpayer or by anyone else. Prior to the Supreme Court's decision in Badaracco, the Tax Court and two circuit courts of appeals had applied a limitations period once an honest amended return was filed, 5 but two other circuit courts of appeals had held that no period of limitations is applicable in such cases. ${ }^{6}$

As will be shown below, the Supreme Court's eight-to-one decision in Badaracco was not merely poorly reasoned and erroneous; it was an egregious misapplication of the principles of statutory construction. The issue resolved by the Court is not one of great moment, and the Court's mishandling of that issue is not in itself of much consequence. What is interesting is how eight justices of the Court could err in such a seemingly easy case and what that error suggests as to the importance of continuing to provide for Supreme Court review of tax litigation. The case also serves as a useful exemplar of the "do's" and "don'ts" of statutory construction.

Before addressing the lessons to be derived from Badaracco, it is necessary to make good on the author's claim that it can be demonstrated to the satisfaction of a reasonably skeptical reader that the Court's decision was patently wrong and resulted from a poor technique of statutory construction. This is a heavy burden, especially since the decision was reached by an overwhelming majority of the Court and since two courts of appeals and at least one student law review note reached the same result. ${ }^{7}$ The reader must judge whether the author succeeds in satisfying it. This Article will first set forth the Court's reasoning and then will consider how the issue should have been resolved.

4. 52 U.S.L.W. 4081 (U.S. Jan. 17, 1984). Justice Stevens dissented.

5. Dowell v. Commissioner, 614 F.2d 1263 (10th Cir. 1980), vacated, 52 U.S.L.W. 3550 (U.S. Jan. 23, 1984); Britton v. United States, 532 F. Supp. 275 (D. Vt. 1981), affd. mem., 697 F.2d 288 (2d Cir. 1982); Klemp v. Commissioner, 77 T.C. 201 (1981) (reviewed by the court), appeal argued, No. 81-7744 (9th Cir. Dec. 8, 1982).

6. Nesmith v. Commissioner, 699 F.2d 712 (5th Cir. 1983), cert. denied, 52 U.S.L.W. 3550 (U.S. Jan. 23, 1984); Badaracco v. Commissioner, 693 F.2d 298 (3d Cir. 1982), affd., 52 U.S.L.W. 4081 (U.S. Jan. 17, 1984). For an approval of this view, see Note, Amended Returns and the Limitations Period for Tax Fraud, 51 GEO. WASH. L. REv. 600 (1983).

7. See note 6 supra. 


\section{The DeCision In BADARACCO}

The Court's decision in Badaracco rested principally on a purportedly literal reading of section 6501 . Since so much weight was placed on the exact language employed by Congress, the relevant portions are reproduced below:

$\S 6501$. Limitations on assessment and collection

(a) General rule

Except as otherwise provided in this section, the amount of any tax imposed by this title shall be assessed within 3 years after the return was filed (whether or not such return was filed on or after the date prescribed) . . . and no proceeding in court without assessment for the collection of such tax shall be begun after the expiration of such period.

(c) Exceptions

(1) False return

In the case of a false or fraudulent return with the intent to evade tax, the tax may be assessed, or a proceeding in court for collection of such tax may be begun without assessment, at any time.

\section{(3) No return}

In the case of failure to file a return, the tax may be assessed, or a proceeding in court for the collection of such tax may be begun without assessment, at any time.

(e) Substantial omission of items

Except as otherwise provided in subsection (c) -

(1) Income taxes

In the case of any tax imposed by subtitle $\mathrm{A}-$

(A) General rule

If the taxpayer omits from gross income an amount properly includible therein which is in excess of 25 percent of the amount of gross income stated in the return, the tax may be assessed, or a proceeding in court for the collection of such tax may be begun without assessment, at any time within 6 years after the return was filed. ${ }^{8}$

The Supreme Court determined that since the statute of limitations in question is a limitation on the Government, it is to be strictly construed in the Government's favor. ${ }^{9}$ The Court then looked at the statute and observed that the three-year limitations period of section 6501(a) was expressly made inapplicable where section 6501(c) applied. Subsection (c)(1) refers to a "false or fraudulent return." The Court noted that the Internal Revenue Code does not expressly provide for the filing of an amended return, which "is a creature of ad-

8. I.R.C. § 6501 (1982).

9. See E.I. Dupont de Nemours \& Co. v. Davis, 264 U.S. 456, 462 (1924). 
ministrative origin and grace."10 The Court concluded that when Congress referred to a "return" in subsection (c)(1), it meant the original return - not the amended return. The Court noted that when an honest return is filed originally, the period of limitations runs from that date even if an amended return is subsequently filed, ${ }^{11}$ and concluded that this indicates that the return referred to in section 6501 is the original return. Since the fraudulent return described in subsection (c)(1) is the original return, the Court reasoned that the provision in that subsection to permit assessment of the tax at any time continued to be applicable notwithstanding the subsequent filing of an honest amended return.

The Court found support for its decision in the fact that the filing of an honest amended return does not immunize the taxpayer from criminal or civil penalties for having originally filed a fraudulent return. Since the case continues to be one of fraud for purposes of imposing criminal and civil penalties, the Court reasoned that it should likewise remain so for purposes of granting the Government an unlimited period of time to assess the tax.

The Court rejected the taxpayer's contention that a nonliteral construction of the statute was appropriate. The Court pointed out that its task is not to choose among conflicting policies and to pronounce the wisest one; rather, the Court's function in a statutory case is to effectuate the congressional purpose for adopting that provision (as evidenced by the plain language of the statute).

While the Supreme Court rested its decision on a literal interpretation, it noted that if it were free to look to policy considerations, it could isolate several that would support its construction of section 6501 . Since the exclusive ground on which the Court based its decision is a literal construction of the statute, the author will postpone a discussion of those policy considerations until Part V of this Article.

\section{A Literal Construction of the Statute}

The result reached by the majority in Badaracco is grounded on the so-called "literal rule" or "plain meaning rule" of statutory construction. The viability of that approach is questionable. Parts III and IV of this Article examine the recognized principles of statutory construction and address the matter of how those principles should be applied in construing the statute in question. First, however, let

10. 52 U.S.L.W. at 4083.

11. See, e.g., Zellerbach Paper Co. v. Helvering, 293 U.S. 172 (1934). 
us consider whether, even given a literal construction approach, the Court correctly read the statute.

The Court treated a taxpayer's original return and a subsequently filed amendment as two independent "returns." The Court then concluded that section 6501 refers only to the original return. The Court emphasized that the Internal Revenue Code does not provide for an amended return, and thus presumed that an amended return is not the return mentioned in section 6501(c)(1). However, even though administratively created, an amended return has long been an integral part of tax administration. Amended returns are mentioned in section 6213(g)(1) and in numerous Treasury Regulations and administrative rulings. ${ }^{12}$ The Commissioner provides printed forms for taxpayers to use in filing an amended return. ${ }^{13}$ The mere absence of a Code provision authorizing the use of amended returns does not affect the jural significance of such returns nor does it appear to be relevant to the construction of section 6501(c)(1).

Let us consider the literal language of the statute. Section 6501(a) requires that an assessment of tax, or the commencement of an action to collect a tax without assessment, be made within three years after a return was filed. This provision constitutes the statute that limits the time available to the Government to institute a civil proceeding to collect a tax deficiency. By its explicit terms, section 6501(a) applies "[e]xcept as otherwise provided" in that section.

Section 6501(c)(1) provides that "In the case of a false or fraudulent return with the intent to evade tax, the tax may be assessed, or a proceeding in court for collection of such tax may be begun without assessment, at any time." An identical provision is made in section 6501 (c)(3) "[i]n the case of failure to file a return." These two provisions are not statutes of limitations; rather they are suspensions of a limitations period.

In its opinion in Badaracco, the Court disputed the suggestion that sections $6501(\mathrm{c})(1)$ and (3) are suspensions of a limitations period. In so doing, the Court was concerned with the suggestion that the suspension was temporary since the Court deemed it to be permanent. It is not worth quibbling over whether sections 6501 (c)(1) and (3) suspend a statute of limitations or whether they provide for a limitations period of infinite duration. In either case, the crucial question is whether a subsequent event can terminate the application

12. See, e.g., Treas. Reg. §§ 1.1034-1(i)(2); 301.6211-1(a); 301.6402-3(a) (1983); Rev. Rul. 82-81, 1982-1 C.B. 109; Rev. Proc. 79-13, 1979-1 C.B. 494.

13. Forms $1040 \mathrm{X}$ for individuals and $1120 \mathrm{X}$ for corporations. 
of subsection (c)(1) or whether no finite period of limitations can ever be made applicable.

Even a literal construction of a subsection of a statute does not rest entirely on a reading of that subsection alone. At a minimum, the reading must include the entire section of which the disputed provision is a part. Section 6501(c)(1) was not adopted in isolation. It is a subdivision of a subsection of section 6501 and as such is merely one aspect of the congressional plan for that section. To determine that congressional plan and to determine the part that section 6501(c)(1) plays therein, it is necessary to consider the workings of the entire section.

From 1921 to 1954 (when the present Code was adopted) the substance of subsections (c)(1) and (3) was set forth in one sentence of a single subsection of the income tax laws. ${ }^{14}$ The committee reports to the 1954 Code discuss the substantive changes to the 1939 Code provisions that were included in section 6501 of the 1954 Code. ${ }^{15}$ Those reports fail to mention the separation into two subsections of the treatment of the filing of fraudulent returns and the failure to file a return. The obvious inference is that this separation was stylistic and made no substantive change. Precisely the same operative language is used in sections 6501(c)(1) and (3) and in the pre-1954 single provision from which those two subsections were derived. Clearly, then, the two subsections are in pari materia.

Section 6501(c)(3) suspends the period of limitations (or, if one prefers, establishes a period of infinite duration) "[i]n the case of failure to file a return." The balance of section 6501(c)(3) is identical to section 6501(c)(1) - namely, it permits the Government to assess a tax or to begin action for collection without assessment "at any time." As the Supreme Court itself noted in Badaracco, it is settled that this provision means that an assessment or action for collection can take place at any time, so long as there is still a failure of the taxpayer to file a return. Once the taxpayer files a return, even though it is delinquent, there is no longer a "failure to file a return," and so the suspension of or bar to the running of the limitations period is terminated. Consequently, assessment or action for collec-

14. See, for example, section 276(a) of the Internal Revenue Code of 1939, which read as follows:

In the case of a false or fraudulent return with intent to evade tax or of a failure to file a return the tax may be assessed, or a proceeding in court for the collection of tax may be begun without assessment, at any time.

The Court noted this fact, 52 U.S.L.W. at 4083 n.6, but accorded it no weight.

15. S. ReP. No. 1622, 83d Cong., 2d Sess. 583-85 (1954); H.R. REP. No. 1337, 83d Cong., 2d Sess. A413-14 (1954). 
tion without assessment must take place within three years after the delinquent return is filed. ${ }^{16}$

Section $6501(\mathrm{c})(1)$ provides that an assessment or proceeding can take place at any time "[i]n the case of a false or fraudulent return with the intent to evade tax." As noted above, section 6501(c)(1) is in pari materia with section 6501(c)(3). Just as section 6501(c)(3) operates to suspend or toll the limitations period only for so long as there is a failure to file a return, so does section $6501(\mathrm{c})(1)$ suspend or toll the limitations period only for so long as there is a false or fraudulent return. If a taxpayer amends a return so as to correct its false and fraudulent aspects, the return will thereafter cease to be false or fraudulent for purposes of the statute of limitations, and so section $6501(\mathrm{c})(1)$ will cease to suspend the running of the limitations period. A continuation of the suspension of the limitations period (or, if one prefers, a continuation of a period of infinite duration) therefore depends upon the legal effect of filing an amended return.

As previously noted, an amended return is an important procedural device that the Government provides for the reporting of tax liability. While an amended return is mentioned in only one statutory provision, ${ }^{17}$ the term appears frequently in Treasury Regulations and in administrative rulings of the Commissioner. An examination of even a few of these regulatory and administrative provisions is sufficient to ascertain the operation and effect of filing an amended return. An "amended return" is not itself a return, but rather is a modification of the terms of the original return. For example, section 6211(a) defines a tax deficiency as the excess of a taxpayer's tax liability over the sum of certain items, one of which is the amount of tax shown on the taxpayer's return. The Treasury Regulations construe the statutory reference to the amount of tax shown on the return to include any additional tax shown on an amended return even though filed after the due date for the original return. ${ }^{18}$ Similarly, the Commissioner recently permitted a parent and a subsidiary corporation to use an amended return to change an election they had made on their original return as to the manner in which certain inter-company pricing was to be determined. ${ }^{19}$ The amended return was filed after the due date for the original return but prior to the expiration of the limitations period. Of course, a change of elec-

16. Badaracco v. Commissioner, 52 U.S.L.W. 4081 , 4085 (U.S. Jan. 17, 1984); Bennett v. Commissioner, 30 T.C. 114 (1958), acq., 1958-2 C.B. 3; Rev.Rul. 79-178, 1979-1 C.B. 435.

17. See I.R.C. $\$ 6213(\mathrm{~g})(1)(1982)$.

18. Treas. Reg. $\$ 301.6211-1$ (a) (1983).

19. Rev. Rul. 82-81, 1982-1 C.B. 109. 
tion will not be permitted if an amended return is filed after the expiration of the period allowed for making that election or if the statute permitting the election makes an initial choice irrevocable.

The picture that arises from examining these consequences is that an amended return merely modifies the terms of the original return. Thus, the Supreme Court's characterization of an original and amended return as two returns is erroneous. There is only one return - the original return, as it reads before being modified by the amendment and as it reads afterwards. After a taxpayer who filed a fraudulent return files an honest amended return, the terms of the original return are modified so that they are no longer false or fraudulent. Commencing with that date, the suspension of the section 6501(a) period of limitations terminates. With the suspension removed, the three-year limitations period of section 6501(a) begins to run.

This construction conforms to the statutory pattern of section 6501 as a whole. Subsection (a) provides a three-year limitations period only when a tax return is filed. If no return is filed, section 6501(a) does not establish any limitation on the Government's power to assess or collect a tax. The question then arises as to why Congress adopted section 6501 (c)(3) to suspend a limitations period that never commenced to run. The answer is that sections 6501 (c)(1) and (3) merely highlight or clarify the operation of section 6501(a). These provisions must be read together as parts of an integrated plan.

So long as no return is filed, section 6501(a) does not operate, and section 6501(c)(3) emphasizes that fact by stating that no period of limitations runs in such cases. Once a return is filed, section 6501(a) becomes operative and section 6501(c)(3) ceases to apply. While this construction is settled for tax years both before and after the adoption of the 1954 Code, it was not "plainly" stated in the statutory language until the parenthetical clause in section 6501(a) was added as part of the 1954 Code..$^{20}$ Section 6501(a) states that it applies "[e]xcept as otherwise provided in this section." Section 6501(c)(3)

20. Bennett v. Commissioner, 30 T.C. 114, 123-24 (1958), acq., 1958-2 C.B. 3; Paul Haberland, 25 B.T.A. 1370, 1376-77 (1932), acq. , 9-2 C.B. 4 (1932); J.P. Bell Co., 3 B.T.A. 254, 255 (1925).

Sections 275(a) and 276(a) of the Internal Revenue Code of 1939 read as follows:

SEC. 275. PERIOD OF LIMITATION UPON ASSESSMENT AND COLLECTION. Except as provided in section 276

(a) GENERAL RULE. - The amount of income taxes imposed by this chapter shall be assessed within three years after the return was filed, and no proceeding in court without assessment for the collection of such taxes shall be begun after the expiration of such period. 
might be said to provide otherwise since it permits assessment at any time in the case "of failure to file a return." A question could be raised as to whether the reference to a "return" in section 6501(c)(3) incorporates delinquent returns or whether the authorization to assess "at any time" suggests that only a timely return precludes the operation of section 6501(c)(3). The 1954 Code's insertion in section 6501(a) of a parenthetical clause expressly applying that section to delinquent returns removed any ambiguity from the statute; but even without that explicit parenthetical clause, it is a settled construction of the ambiguous language of the pre-1954 version that the filing of a delinquent return terminated the operation of the antecedent of section 6501(c)(3), so that the antecedent to section 6501(a) then operated to impose a limitations period. ${ }^{21}$ This construction reflects a statutory pattern of mutual exclusivity for subsection (a) and subsection (c)(3) (and for their antecedent provisions) - namely, that subsection (a) does not operate when subsection (c)(3) applies and conversely that subsection (c)(3) does not operate when subsection (a) is applicable.

The same statutory pattern is evident in subsection (a) and subsection (c)(1). Section 6501(a) operates only if a "return" is filed. The "return" referred to in section 6501(a) is a return filed by a taxpayer evincing an "honest and genuine endeavor to satisfy the law,"22 one which places in the hands of the Government the information from which a proper assessment of the tax due can be made. ${ }^{23} \mathrm{~A}$ return that does not provide the required disclosure does not trigger the three-year statute of limitations. When subsections (a) and (c)(1) are examined together, it is evident that there is the same mutual exclusivity that exists between subsection (a) and subsection (c)(3). Thus, when a fraudulent or false return is filed, sec-

SEC. 276. SAME - EXCEPTIONS.

(a) FALSE RETURN OR NO RETURN. - In the case of a false or fraudulent return with intent to evade tax or of a failure to file a return the tax may be assessed, or a proceeding in court for the collection of such tax may be begun without assessment, at any time.

The 1954 Code added an explicit parenthetical statement in $\$ 6501$ (a) (which corresponds to section 275(a) of the 1939 Code) that the limitations period described therein applies "whether or not such return was filed on or after the date prescribed." The Committee Reports to the 1954 Code state that $\$ 6501$ did not change existing law as to the treatment of income tax returns. H.R. ReP. No. 1337, 83d Cong., 2d Sess. A413 (1954); S. ReP. No. 1622, 83d Cong., $2 \mathrm{~d}$ Sess. 583-84 (1954). Thus, the addition of the parenthetical clause to $\$ 6501$ (a) merely codified the accepted construction of the two provisions that are now set forth in $\S 6501$ (a) and (c).

21. See note 20 supra.

22. Zellerbach Paper Co. v. Helvering, 293 U.S. 172, 180 (1934).

23. Cf. Florsheim Bros. Dry Goods Co. v. United States, 280 U.S. 453, 460 (1930) (construing prior law). 
tion 6501(a) does not apply and section 6501(c)(1) is the operative provision. Once the return is corrected by an amended return so as to cure its fraudulent nature, section 6501 (c)(1) ceases to apply and section 6501(a) can then operate. Accordingly, the three-year limitations period will commence to run from the date that a taxpayer amends his fraudulent return to provide an honest statement.

As noted in Part I, the Supreme Court found support for its construction of section 6501 by analogizing to the legal rule that a taxpayer cannot escape from criminal and civil penalties for fraud by filing an honest amended return. These rules are not relevant to the issue at hand. If the act of filing the original return constituted a willful attempt to evade or defeat the tax as proscribed by section 7201, the original filing itself constituted the crime and cannot be expunged retroactively by filing an amended return. Similarly, section 6653(b) provides civil penalties for fraud that causes an "underpayment" of tax, and section 6653(c)(1) defines an underpayment so as to preclude consideration of the tax shown on a return filed after the due date. This language bars consideration of an amended return unless it is filed before the due date for the original return. The specific statutory language in sections 7201 and 6653 is quite different from that found in section 6501. More important, the policies involved are unrelated. An attempt to defeat a tax is a punishable offense, and the taxpayer's subsequent remorse will not preclude his punishment. But, as explained in Part IV of this Article, the suspension of a statute of limitations is not a penal provision.

One way to test the validity of the Court's "literal" construction is to apply it to a different set of circumstances and consider whether the result reached squares with the congressional policy for adopting that provision. The Court held in Badaracco that only the original return is to be taken into account in determining whether section 6501 (c)(1) or section 6501(a) applies. Consider the application of that construction to the following set of facts.

$X$ filed an honest return in which $X$ innocently omitted a significant amount of income because of an erroneous judgment that the amount in question was excluded from gross income as a gift. The amount excluded was equal to twenty percent of the amount of gross income reported by $X$ on the return. One year later, $X$ discovered his error and became aware that his income was underreported on the prior year's return. Since the original return was nonfraudulent, there is a three-year period of limitations on the Government's right to assess a deficiency for that year, and $X^{\prime}$ s subsequent discovery of an error should not affect that period even if $X$ were to refrain from 
disclosing the error. Whatever other consequences $X$ 's silence might incur, the running of the limitations period would not be affected (especially in light of Badaracco). However, $X$ decides to file an amended return. In doing so, $X$ deliberately includes in the amended return only a portion of the unreported income, and thus files a fraudulent amended return. Since Badaracco held that section $6501(\mathrm{c})(1)$ refers only to the original return (i.e., to the return as originally filed), the statute of limitations on what has become a fraudulent return will expire three years after the original return was filed. It is questionable whether this result comports with the congressional aim in adopting section 6501(c)(1), and the author doubts that most courts would reach such a conclusion if this issue were litigated. But, to avoid this result, a court would have to strain its reading of Badaracco to escape from the holding of that case.

\section{A Proper Approach to Construing Section 6501 Requires That the Legislative Policies for adopting That Provision Be Taken into ACCOUNT}

The Court's construction of section 6501 provides the Government with unlimited time to assess and collect a tax even where the taxpayer has made a complete and honest disclosure of all of the relevant facts. As will be shown in Part IV, that construction is counter to the policies underlying statutes of limitation of all types and is inconsistent with the congressional purpose in adopting section 6501. Before examining the legislative policies underlying the adoption of section 6501, let us first consider the propriety of the Court's reliance on a literal construction.

The Court held that since the plain language of the statute provides that in the case of a false or fraudulent return the tax can be assessed at any time, in the absence of an explicitly worded exception to that provision or of an ambiguity in the language, the plain meaning of the statute must prevail. The Court thus relied on a "literal rule" or "plain-meaning rule" of statutory construction. This approach contrasts with the so-called "golden rule" of construction, which construes a statute according to its legislative purpose even if that requires adding, deleting or substituting language. ${ }^{24}$ While numerous cases can be found to support either of those two approaches, the more recent Supreme Court decisions (other than

24. See generally H.M. HarT \& A. SAChS, The LEGal Process 1144-1286 (unpublished). 
Badaracco) have given great weight to legislative purpose. ${ }^{25}$ In Chapman v. Houston Welfare Rights Organization, ${ }^{26}$ the Supreme Court stated, "As in all cases of statutory construction, our task is to interpret the words of these statutes in light of the purposes Congress sought to serve."27 In Watt v. Alaska, ${ }^{28}$ the Court stated:

[T] he plain-meaning rule is "rather an axiom of experience than a rule of law, and does not preclude consideration of persuasive evidence if it exists." . . . The circumstances of the enactment of particular legislation may persuade a court that Congress did not intend words of common meaning to have their literal effect. ${ }^{29}$

Even those who adhere to a plain-meaning rule likely would agree that the "plain language" cannot control if it leads to an absurd result. To take a time-honored example, consider the construction of a law adopted in Bologna, Italy a few hundred years ago "that whoever drew blood in the streets should be punished with the utmost severity." A question arose as to whether that law called for the punishment of a surgeon who opened the vein of a person who had fallen down in the street in a fit. The literal or plain terms of the statute clearly applied to the surgeon's actions, but the language of the statute, when read in light of common experience, strongly suggests that it was not aimed at medical treatment provided by a surgeon. The statute was deemed not to apply. ${ }^{30}$

In effect, where the literal language of a statute conflicts with the apparent purpose of the act, which is discovered by examining the entirety of the statutory provision and of related statutes and by considering the background which gave rise to the adoption of the statute, the language can be said to be ambiguous. In any event, regardless of how narrow a reading is given to the term "ambiguous," section 6501 contains ambiguities which can be resolved only by resort to the legislative purpose. Section 6501(c)(1) cannot be read in isolation from the rest of the statute. It operates together with section 6501(a) and section 6501(c)(3), inter alia, to comprise an overall statutory scheme as to the imposition of a period of limitations on the Government's power to assess or collect taxes.

As the Court noted in Badaracco, there is no explicit reference in section 6501 to amended returns or to the effect on that provision of

25. E.g., Rose v. Lundy, 455 U.S. 509, 516-18 (1982).

26. 441 U.S. 600 (1979).

27. 441 U.S. at 608.

28. 451 U.S. 259 (1981).

29. 451 U.S. at 266 (quoting Boston Sand Co. v. United States, 278 U.S. 41, 48 (1928) (citation omitted)).

30. See 2 W. Blackstone, Commentaries *61 (8th ed. 1778). 
correcting false statements in an original return by filing an accurate amended return. The Court, relying on a plain-meaning approach, concluded that the failure to mention amended returns means that they have no effect on the operation of the statute. But that reading of the statute begs the question. One could just as easily have concluded that, in light of the settled administrative practice of accepting amended returns, Congress' failure explicitly to restrict section 6501 to original returns demonstrates its intent to include amended returns. Section 6653(c)(1) supports this conclusion by demonstrating that when Congress intends to exclude amendments, "it knows how unambiguously to accomplish that result." 31 The failure of Congress to address the effect of filing an amended return merely raises the question of whether that omission resulted from a deliberate decision of Congress to include or give no effect to such amendments or whether it was an inadvertence stemming from the failure of Congress to consider this question; it does not answer the question.

As previously noted, an amended return is an important procedural device provided by the Government for the correction of an original return. There are numerous regulations and administrative rulings that give the same effect to an amended return as is provided to an original return even though the operative statute makes no reference to an amended return. ${ }^{32}$ The Government's construction of various statutory provisions that use the term "return" to encompass amended returns in some such statutes and to preclude amended returns in others suggests that the question of whether a statutory reference to a return encompasses amended returns must be resolved by referring to the legislative purpose of the statutory provision under review.

It appears that when Congress adopted section 6501(c)(1), it gave no thought to the effect to be given to the taxpayer's subsequent filing of an accurate amended return. The issue in question thus falls within the most common area of statutory construction problems namely, it presents an unanticipated problem. The proper construction of statutes where an unanticipated problem arises was discussed

31. Badaracco, 52 U.S.L.W. at 4084 (making the opposite argument for $\S 6501$ ).

32. In addition to the provisions previously mentioned, see note 12 supra, consider Bookwalter v. Mayer, 345 F.2d 476, 479-81 (8th Cir. 1965) (permitting an election of the installment method of reporting to be made on an amended return), and Rev. Rul. 83-36, 1983-9 I.R.B. 10 (holding that the underpayment of estimated tax by an individual is determined by reference to the tax shown on an amended return if the amended return is filed on or before the due date of the original return). 
by the Supreme Court in Rose v. Lundy ${ }^{33}$ as follows:

In 1948, Congress codified the exhaustion doctrine in 28 U.S.C. section 2254 , citing Ex parte Hawk as correctly stating the principle of exhaustion. Section 2254 , however, does not directly address the problem of mixed petitions. To be sure, the provision states that a remedy is not exhausted if there exists a state procedure to raise "the question presented," but we believe this phrase to be too ambiguous to sustain the conclusion that Congress intended to either permit or prohibit review of mixed petitions. Because the legislative history of section 2254, as well as the pre-1948 cases, contains no reference to the problem of mixed petitions, in all likelihood Congress never thought of the problem. Consequently, we must analyze the policies underlying the statutory provision to determine its proper scope. Philbrook $v$. Glodgett, 421 U.S. 707, 713 (1975) (" In expounding a statute, we must . . . look to the provisions of the whole law, and to its object and policy" "(citations omitted)); United States v. Bacto-Unidisk, 394 U.S. 784, 799 (1969) ("where the statute's language seem[s] insufficiently precise, the 'natural way' to draw the line 'is in light of the statutory purpose'" (citation omitted)); United States v. Sisson, 399 U.S. 267, 297-298 (1970) ("The axiom that courts should endeavor to give statutory language that meaning that nurtures the policies underlying legislation is one that guides us when circumstances not plainly covered by the terms of a statute are subsumed by the underlying policies to which Congress was committed"); Unexcelled Chemical Corp. v. United States, 345 U.S. 59, 64 (1953) ("Arguments of policy are relevant when for example a statute has an hiatus that must be filled or there are ambiguities in the legislative language that must be resolved"). ${ }^{34}$

In light of the acknowledged construction of section 6501(c)(3), which was described earlier in this Article, to assert that Congress intended to provide an infinite period of time for the assessment and collection of a tax in the instant circumstance is to assert that Congress intended to provide different treatment for a fraudulently motivated failure to file a return from the treatment accorded to a filing of a fraudulent return. In the former case, it is acknowleged that a subsequent filing of a delinquent return will begin the running of the three-year limitations period. It is inconceivable that the legislature would intentionally prevent the application of a limitations period in one such case but not in the other.

The Court did not attempt to reconcile its construction of section 6501 (c)(1) with the acknowledged operation of section 6501(c)(3). Instead, it fell back on a plain-meaning approach to statutory construction and essentially shrugged off the obvious inconsistency of treatment as one of the anomalies of statutory law.

33. 455 U.S. 509 (1982).

34. 455 U.S. at 516-18 (footnotes omitted). 
The Supreme Court sought to justify its adoption of the plainmeaning rule by invoking the rule that where a statute of limitations is applicable to the Government it should be strictly construed in the Government's favor. It is difficult to believe that the result reached in Badaracco actually turned on the application of what amounts to a canon of statutory construction. Such "rules" are merely reflections of general experience; they should not be applied rigidly. The value of such rules is to provide a guide as to the likely purpose of the legislature where explicit evidence of that purpose is unavailable or unconvincing. But if the legislative policy for providing a limitations period would be thwarted by a strict construction, then the legislative policy (rather than a literal reading of the statute) should be enforced. It would be a strange principle of construction that would elevate generalizations to such a degree that a court would adhere to them rather than ascertain and implement the relevant congressional purpose.

The Supreme Court did not explain what weight should be given to the "strict construction" rule that it adopted. Does it mean anything more than that in cases where congressional purpose cannot be ascertained with reasonable certainty, the literal language should prevail if it favors the Government? If so, how certain of a contrary congressional purpose must a court be before it can implement such a purpose? The rule surely cannot require certainty beyond any doubt or even beyond a reasonable doubt. If the statutory language and history make it more likely than not that Congress intended a certain application, it would be a poor rule of construction that would insist that the statute be interpreted otherwise. The canon cited by the Court is only one factor to weigh with other evidence of statutory purpose; it is not a shibboleth to substitute for a careful inquiry into congressional purpose.

\section{Policy Considerations and the Congressional Purpose for Adopting Section 6501 ARe Contrary TO THE Badaracco RESULT}

\section{A. Function of a Statute of Limitations}

A major purpose of a statute of limitations is to "assure fairness to defendants. Such statutes 'promote justice by preventing surprises through the revival of claims that have been allowed to slumber until evidence has been lost, memories have faded, and witnesses have 
disappeared." "35 It was established long ago that "[s]tatutes of limitation are founded on sound policy. They are statutes of repose, and should not be evaded by a forced construction." 36

The same considerations of providing repose for defendants led Congress to limit the period of time in which the Commissioner can assess federal tax deficiencies. There has been no manifestation of a congressional policy in favor of an unlimited assessment period. ${ }^{37}$ Once a taxpayer has furnished the Government with an honest return, Congress has given the Government a definite period within which to determine any errors; after that period, the taxpayer is assured that his tax liability cannot be reopened. ${ }^{38}$ When litigation is initiated many years after a return was filed, a taxpayer likely will have disposed of documents and records pertaining to those years. The availability of witnesses is also likely to be impaired. One of the reasons for granting repose to a taxpayer is to limit the number of years for which a person should feel obligated to retain records. A limitations period, therefore, should be disregarded only when there are strong countervailing reasons for denying a taxpayer the repose that Congress sought to provide.

\section{B. Suspension of Limitations Period Where Pertinent Information Has Been Denied to the Government or Where False Information Has Been Provided}

If a return is filed in good faith, the Government is given only a limited number of years (usually three) to discover errors in the return and to set in motion the procedures that permit it to challenge the accuracy of the return. However, the limitations period on assessment and collection of taxes is suspended in three circumstances set forth in section 6501(c)(1)-(3). The reason for precluding the running of a limitations period in those three circumstances is that each involves a situation where the taxpayer deliberately deprives the Government of information necessary to determine the tax or deliberately gives false information to the Government in order to mislead it in determining the tax. ${ }^{39}$ The suspension is not penal. Rather, it is remedial for Congress to deny a taxpayer the repose of a

35. Burnett v. New York Central R.R., 380 U.S. 424, 428 (1965) (quoting Order of R.R. Telegraphers v. Railway Express Agency, 321 U.S. 342, 348-49 (1944)).

36. Pillow v. Roberts, 54 U.S. (13 How.) 472, 477 (1851); see also Clementson v. Williams, 12 U.S. (8 Cranch) 72, 74 (1814).

37. See, e.g., Bennett v. Commissioner, 30 T.C. 114, 123-24 (1958), acq., 1958-2 C.B. 3.

38. See Germantown Trust Co. v. Commissioner, 309 U.S. 304, 309 (1940); Mabel Elevator Co., 2 B.T.A. 517, 519 (1925), acq. , 6-1 C.B. 4 (1927).

39. E.g., Klemp v. Commissioner, 77 T.C. 201, 205-06 (1981) (reviewed by the court), ap- 
limitations period where to grant such repose would require the Government to discover the taxpayer's deficiency and to take appropriate action before the Government was given any notice of the problem. If the limitations period were not so suspended, a taxpayer who defrauded the Government and who succeeded in avoiding detection for over three years (or perhaps for over six years if section $6501(\mathrm{e})(1)(\mathrm{A})$ applies) would be permitted to retain the benefits of his fraud. The statutory suspension of the limitations period (or, if one prefers, the establishment of an unlimited period) prevents that undesirable result from taking place.

\section{Commencement of Limitations Period Where an Honest and Complete Return or Amended Return Has Been Filed}

After a taxpayer files an honest return (or, in the case of a fraudulent return, an honest amended return), the Government has available all of the information that it would have had if such a return had been filed initially in a timely manner. Once the taxpayer has placed that information in the Government's hands, there is no justification for continuing the suspension of the limitations period unless Congress intended to use the suspension as a punitive measure.

The Court has acknowledged and the Commissioner has acquiesced in the "settled" principle that the filing of an honest delinquent return triggers a limitations period even though the taxpayer had failed to file on time in an attempt to defraud the Government. ${ }^{40}$ In Bennett $v$. Commissioner, ${ }^{41}$ the case which established that principle, the Tax Court stated:

We must next determine whether the statute of limitations operates as a bar in petitioners' favor. Section 275 (a) provides that the income taxes must be assessed within 3 years after the return was filed, but, pursuant to section 276(a), in the case of a false or fraudulent return or of a failure to file a return, the tax may be assessed at any time. Accordingly, if petitioners had not filed their so-called delinquent returns, there would be no bar whatever. But we are of the opinion that the filing of such returns - provided that they were not false or fraudulent - would be sufficient to start the running of the period of limitations, notwithstanding that they could not operate to wipe out the so-called fraud penalty which had already accrued. For, once a nonfraudulent return is filed, putting the Commissioner on notice of a taxpayer's receipts and deductions, there can be no policy in favor of permitting assessment thereafter at any time without limitation. We think that the

peal argued, No. 81-7744 (9th Cir. Dec. 8, 1982); Bennett v. Commissioner, 30 T.C. 114, 123-24 (1958), acq., 1958-2 C.B. 3.

40. Badaracco, 52 U.S.L.W. at 4085.

41. 30 T.C. 114 (1958), acq., 1958-2 C.B. 3. 
statute of limitations begins to run with the filing of such returns. ${ }^{42}$

This settled construction of subdivision (c)(3) belies the argument that (c)(1) is a punitive provision. It is inconceivable that Congress would use the suspension of the limitations period as a punitive measure for persons who file a false return for fraudulent purposes but not for persons who fraudulently attempt to avoid the tax by failing to file a return. A difference of purpose for section 6501(c)(1) and (c)(3) is especially unlikely since (as previously noted) for thirtythree years - from 1921 until the adoption of the 1954 Code - the substance of those two subdivisions was included in a single sentence of one subsection of the income tax laws.

The Court held that once a fraudulent return is filed no limitations period can ever apply regardless of the taxpayer's subsequent disclosure of the facts by filing an honest and complete return. Consequently, if $B$ were to file a fraudulent return on April 15 (a Friday) and, after attending a religious service that weekend, had a change of heart and filed an honest amended return on the following Monday, April 18, the statute of limitations for the assessment and collection of the tax would never run. Even $B$ 's death would not establish any bar to the Government's power to assess and litigate tax issues for the year for which $B$ 's original return was filed. Under section 6901(c)(1), the Government can assess a liability against a transferee of $B$ within one year after the expiration of the period of limitation for assessment against the transferor $(B)$. Since, according to the Supreme Court's construction, there is no expiration of the power to assess against $B$, the one-year expiration period for assessing the tax against $B$ 's transferee will never commence to run. ${ }^{43}$ Consequently, even many years after $B$ 's death, the Government would not be barred from litigating such issues with the beneficiaries of $B$ 's estate or with the legatees of deceased beneficiaries.

As previously noted, the purpose of the limitations in section 6501 is to provide repose for taxpayers after the Government has had a reasonable period in which to determine whether to contest the tax reported by the taxpayer. Certain exceptions which suspend or extend the period of limitations are provided by section 6501(c) and (e) where the taxpayer provides the Government either with false information or with insufficient information to determine whether to seek additional taxes. In the absence of compelling considerations to the contrary, the most likely intent of Congress is that

42. 30 T.C. at 123-24 (citation omitted).

43. See Leo Kubik, 1974 T.C.M. (P-H) If 74,062. 
the period of limitations will run in the normal course once the taxpayer has provided the Government with the relevant information. In other words, once the special reason for suspending the period of limitations is removed, the suspension itself should cease to operate. 44

An additional factor demonstrates that the Supreme Court's construction is contrary to congressional intent. As previously noted, section 6501(c)(1) and (3) contain identical language and are in pari materia. The Supreme Court, ignoring this common origin and language, concluded that these two provisions are to be construed as producing drastically different consequences. According to the Court, a taxpayer who attempts to avoid his tax by fraudulently failing to file a return can terminate the suspension of the limitations period by filing a return at a later date, but if the commission of his fraud was effected by filing a false return, he cannot terminate the suspension of that period by filing an amended return or by any other means. The question raised by this comparison is not whether it is desirable to permit wayward taxpayers to terminate the suspension period; there is no dispute that a suspension caused by section 6501 (c)(3) can be so terminated. 45 Nor is the question whether the rule applicable to section 6501(c)(3) should be extended to section $6501(\mathrm{c})(1)$ or whether it would be inequitable to provide different consequences. Rather, the narrow question presented is whether Congress is likely to have intentionally provided such disparate consequences to acts which are distinguishable only on a factual difference that has no substantive relevance. The thirty-three-year parallel history of the two suspension provisions as integrated parts of a single statutory sentence makes it clear that the Court's construction is contrary to congressional intent.

\section{The Policy Considerations That Were Raised by the SUPREME COURT IN BADARACCO}

While the Supreme Court in Badaracco applied the literal construction rule, the Court did note several policy considerations that,

44. This argument, which is apparent from the structure of $\S 6501(a)$ and (c), is even more explicit in $\$ 6501(\mathrm{e})(1)(\mathrm{A})(\mathrm{ii})$ :

(ii) In determining the amount omitted from gross income, there shall not be taken into account any amount which is omitted from gross income stated in the return if such amount is disclosed in the return, or in a statement attached to the return, in a manner adequate to apprise the Secretary of the nature and amount of such item.

This is "plain language" evidencing Congress' concern with giving the Service a fair chance to discover a problem and Congress' decision to start the statute of limitations running once an adequate disclosure is made.

45. See note 16 supra. 
in its view, supported its determination that no period of limitations applies to an initial fraudulent return. Let us examine those several policies.

\section{A. The Six-Year Period of Limitations Provided by Section $6501(e)(1)(A)$}

Under section 6501(e)(1)(A), if a taxpayer improperly omits from his return an amount in excess of twenty-five percent of the gross income that was reported on the return, the period of limitations is six years instead of the usual three years. This provision does not apply if one of the suspension provisions of section 6501(c) is applicable. Where section 6501(e)(1)(A) applies to a return, the lower courts have uniformly held that the six-year period of limitations cannot be shortened by filing a corrected amended return. 46 The Supreme Court has never passed on this construction but in Badaracco acted on the assumption that it was correct. The Court concluded that since an amended return cannot shorten the six-year limitations period of section 6501(e)(1)(A), there is no reason to believe that Congress intended to permit an honest amended return to shorten the "any time" provision of section 6501(c)(1).

There are several reasons why the judicial construction of section 6501(e)(1)(A) should not be extended to section 6501(c)(1). It was established at an early date that the period of limitations for assessing a tax is measured from the date that the original return is filed without regard to subsequent amended returns that might be filed. ${ }^{47}$ This construction was deemed necessary to prevent an amended return from lengthening the period of limitations since if that occurred it would deter taxpayers from correcting their returns. When the question later arose as to whether an amended return could shorten the period of limitations (where, for example, the original return excludes a substantial amount of gross income and the amended return is filed at a date when there is more than three years remaining on the period established by section $6501(\mathrm{e})(1)(\mathrm{A})$ for the original return), the courts may have erred by mechanically applying the original return rule without questioning whether different considerations were present. Nevertheless, the substitution of a six-year period of limitations for a three-year period is so much less drastic than the substitution of a period of infinite duration that it is less obvious in

46. E.g., Houston v. Commissioner, 38 T.C. 486, 489 (1962); cf. Bennett v. Commissioner, 30 T.C. 114,125 (1958), acq., 1958-2 C.B. 3 (construing $\$ 275$ (c) of the Internal Revenue Code of 1939); Goldring v. Commissioner, 20 T.C. 79, 82 (1953) (same).

47. See note 11 supra. 
the former case that Congress did not intend that result to occur. Indeed, when this construction was first adopted, it dealt with a predecessor of section 6501(e)(1)(A) which provided a five-year period of limitations so that an extension of only two years over the usual three-year period was involved. ${ }^{48}$ If the amended return were filed immediately after the filing of the original return, there would be an extension of only two years, but typically an amended return would be filed at a later date so that an even shorter period would have been involved in those pre-1954 cases.

The Supreme Court asserted that if an amended return could shorten the limitations period for purposes of section 6501(c)(1) but not for section 6501(e)(1)(A), it would lead to anomalous consequences. If such were the case, a taxpayer who filed a return in which he fraudulently understated his gross income by an amount in excess of twenty-five percent of the gross income reported on the return would be able to shorten the limitations period for assessing his tax by filing an amended return while a taxpayer who innocently omitted a like amount of income could not do so.

Even if that disparity of treatment were deemed to be anomalous, that would merely underline the question as to whether the current construction of section 6501(e)(1)(A) is correct. The Supreme Court has never ruled on the effect that filing an amended return has on the application of section 6501(e)(1)(A), and the lower court decisions on this issue may well be in error. In any event, as Justice Stevens noted in his dissent, section $6501(\mathrm{c})(1)$ is more closely tied to section $6501(\mathrm{c})(3)$ than it is to section 6501(e)(1)(A), and so if a choice has to be made whether to have disparate treatment with either section 6501(c)(3) or section 6501(e)(1)(A), it is more likely that Congress intended subsection (c)(1) be made consistent with subsection (c)(3) since those two provisions are in pari materia.

\section{B. Investigative Problems}

The Supreme Court asserted that when there is fraud in a case, the Government has greater difficulty in obtaining evidence and in meeting the burden of proof that must be satisfied to impose fraud penalties than it would in nonfraudulent cases. The Court stated that although the filing of an honest return will assist the Government in uncovering evidence and establishing its case, it does not erase all of the handicap which the Government must endure in fraud cases. The Court feared that the normal three-year period of

48. See I.R.C. \& 275(c) (1939) (repealed 1954). 
limitations "may not be enough time for the Commissioner to prove fraudulent intent." 49

The Court's approach at this point again demonstrates the inadequacy of its chosen method of statutory construction. After stating its task fairly well, the Court is led astray by the plain meaning rule. Since it read the plain language of the statute as providing the Government with an unlimited time to proceed, the Court apparently felt that any policy support for that construction would be sufficient to justify it. However, such policy support is exactly what the Court failed to provide, and what it could not provide in light of the available statutory evidence of congressional intent. Initially, one might observe that the Court did not refer to any empirical data or legislative history to support its assertion that the Government has great difficulty in establishing its case in these circumstances or to support its assumption that the added difficulty is of such magnitude as to make. a three-year limitations period inadequate and to warrant granting the Government an unlimited period of time to investigate and decide whether to go forward. But the Court's real error here was in asking (and attempting to answer) the wrong question. The Court addressed the policy considerations on the basis that it had to find no more than some modicum of support for believing that Congress intentionally created a longer limitations period than three years. But that is not the proper issue. The question is whether the more likely intention of Congress was to limit the Government to three years after an honest amended return was filed or to impose no time limitation at all on the Government in such cases. And on that issue, the policies as enacted by Congress point unambiguously toward the establishment of a three-year limitations period.

As previously explained, it is settled that the three-year limitations period commences to run when a delinquent income tax return is filed even where the taxpayer's purpose in failing to file on time was an attempt to defraud the Government and to defeat the tax..$^{50}$ This construction was established prior to the adoption of the 1954 Code. The willful failure to file a tax return can constitute tax fraud if there is evidence of an overt act that indicates a fraudulent purpose. $^{51}$ The failure to file a return has been found to constitute tax fraud in a sufficiently large number of cases to make it a virtual certainty that when Congress adopted the 1954 Code it was aware that a meaningful number of the persons who fail to file do so for fraudu-

49. Badaracco, 52 U.S.L.W. at 4085.

50. See note 16 supra.

51. See Bennett v. Commissioner, 30 T.C. $114,122-23$ (1958), acq., 1958-2 C.B. 3. 
lent purposes. Yet, in adopting the 1954 Code, Congress added the parenthetical clause to section 6501(a) which codified the construction of that provision that limited the Government's time period for proceeding in such cases to three years after a delinquent return is filed. In dealing with the limitations problem, Congress did not distinguish the fraudulent taxpayer from the negligent or innocent taxpayer who misses a deadline for filing a return. Any investigative problems that arise when fraud and deceit are present are at least as prevalent when the taxpayer files no timely return as they are when the taxpayer files a false return. Regardless of how burdensome the Government's task of establishing fraud may be, the critical issue is whether Congress deemed it to be of such magnitude as to warrant permanently suspending the statute of limitations. It is inconceivable that Congress would have deemed the Government's task to be insufficiently burdensome to preclude the imposition of a three-year limitations period when a taxpayer fraudulently failed to file a return on time but would have deemed the same burden as sufficient to preclude the availability of any limitations period when a false return was filed initially and later corrected.

The asserted fear of the magnitude of the Government's burden is even less convincing when it is considered that the Government has the benefit of being able to compare the amended return with the original false return. The contrast between the terms of the original return and the modifications made by the honest amended return should be of considerable assistance to the Government in establishing its case. Obviously, the Government's difficulties in establishing fraud are greater when no return is filed than when a false return is filed and later corrected; yet, it is settled that in the former case, the filing of an honest delinquent return will start the running of a threeyear limitations period. ${ }^{52}$

\section{The Unavailability of the Summons Procedure as an Investigative Tool}

As additional support for its assertion that a three-year limitations period is insufficient time in light of the added burden of investigation in fraud cases, the Court pointed out that once the Service refers a case to the Department of Justice for criminal prosecution, it is barred from using the summons procedure authorized by section 7602 to examine books, documents and witnesses. ${ }^{53}$ The Court de-

52. See note 16 supra.

53. See United States v. La Salle Natl. Bank, 437 U.S. 298, 318 (1978). 
termined, therefore, that there is a policy justification for permitting the Service an unlimited time to assess and collect the tax so that it can defer the civil litigation until after the criminal prosecution has been resolved.

Presumably, the Service does not refer a case for criminal prosecution unless it already has substantial evidence that fraud is present. It appears doubtful that loss of further use of the summons procedure is a meaningful obstacle to the Service's civil investigation.

Section 6531(2) limits the Government to a period of six years from the date that a fraud was committed to commence a criminal prosecution. In that six-year period, the Government has to uncover the fraud and garner sufficient evidence to warrant prosecuting the taxpayer. Congress did not make available the civil summons procedure for investigating criminal fraud and it did not provide the Government with an unlimited period of time to investigate. If such procedures have not been needed for criminal prosecution, where the Government's burden is far greater than it is in civil litigation, it is hardly likely that such procedures are essential for civil litigation in circumstances where the Government already has sufficient evidence to go forward on the criminal aspect of the case. It is even more unlikely that Congress intended to provide an unlimited time period to the Government in order to protect the availability of civil summons procedures.

Even if the loss of further use of summons procedures were a significant problem for the Government, the identical problem exists when a taxpayer fails to file a return for the fraudulent purpose of attempting to defeat the tax. Yet, if the taxpayer files a delinquent honest return, the three-year limitations period commences to run even if the Government concurrently goes forward with a criminal prosecution. Congress obviously did not rate this problem as one of sufficient magnitude to override the long-standing policies that have induced legislatures to establish limitations on the period of time available to determine whether to litigate a dispute. There is no reason to believe that Congress felt differently in the circumstances where the taxpayer filed a fraudulent return.

\section{The Supreme Court's Role in Tax Litigation}

Even if the reader agrees with the author that the decision of the majority in Badaracco was patently wrong, the question arises as to what purpose, other than inspiring corrective congressional action, there is in demonstrating that the Court made one bad decision. The 
significant aspect of this tax case is that it did not involve the appplication of a complex, technical statutory provision. Rather, the case concerned a statute of limitations and the difficulties encountered by the Government in administering a specialized area of the law. These are common issues of general concern that presumably are brought before the Supreme Court in a variety of contexts. Yet, in confronting these issues, eight Justices of the Court did not perform especially well.

Proposals are occasionally advanced to withdraw tax cases (other than cases raising constitutional issues) from the Supreme Court's jurisdiction and to substitute a specialized court of last resort to review all tax litigation. A frequent objection to such proposals is that it is important to preserve the input of judges who hear a wide range of cases and who thus have a broader perspective than would a specialized court restricted to a narrow technical field. ${ }^{54}$ One possible method of testing the validity of this objection would be to examine the Supreme Court's disposition of a number of tax cases in which broader issues were present, ${ }^{55}$ although it may be hard (if not impossible) to reach a consensus as to the identity of the cases which present broader issues and as to the quality of the Court's disposition of those issues. This Article should provide one datum of evidence that could be accumulated with evaluations of other tax decisions in order to rate the Supreme Court's performance in this area.

There is no suggestion here that the Supreme Court performs more poorly in tax cases than do other courts. Indeed, in the author's view, the Supreme Court does a better job of passing on tax issues than do other courts. The question is whether the members of the Supreme Court have special experience or insights that make it especially important that the Court retain jurisdiction over tax litigation even if other policies point to relieving the Court of that burden. Some persons (including the author) have harbored doubts that the Court makes a special contribution to tax law in that respect, and Badaracco may reinforce those doubts.

54. See Craig, Federal Income Tax and the Supreme Court: The Case Against a National Court of Tax Appeals, 1983 UTAH L. REv. - (in press).

55. $I d$. 